\title{
Does Person-Organization Fit (P-O Fit) Mediate the Relationship Between Employee Job Satisfaction and Turnover Intention: The Case of Insurance Agents in Malaysia
}

\author{
Oscar Dousin (Corresponding author) \\ Faculty of Business, Economics and Accountancy, Universiti Malaysia Sabah \\ UMS Road, 88400, Kota Kinabalu, Sabah, Malaysia \\ E-mail: odousin@ums.edu.my/ oscardousin@gmail.com
}

Pei Sung Toh

Faculty of Business, Economics and Accountancy, Universiti Malaysia Sabah

UMS Road, 88400, Kota Kinabalu, Sabah, Malaysia

Arsiah Bahron

Faculty of Business, Economics and Accountancy, Universiti Malaysia Sabah

UMS Road, 88400, Kota Kinabalu, Sabah, Malaysia

Iklima Husna Abdul Rahim

Faculty of Business, Economics and Accountancy, Universiti Malaysia Sabah UMS Road, 88400, Kota Kinabalu, Sabah, Malaysia

Received: March 8, 2020 Accepted: April 1, 2020 Online published: April 9, 2020 doi:10.5296/ijhrs.v10i2.16635 URL: https://doi.org/10.5296/ijhrs.v10i2.16635

\begin{abstract}
Turnover intention is becoming a critical issue in most organization. Employees' are leaving their job due to an alternative job offer with an attractive salary and employment benefits,
\end{abstract}


supportive supervisors and a better work environment. The study examines the relationship between job satisfaction on employee turnover intention as well as the mediating effect of person-organization (P-O) fit among insurance agents in Malaysia. The study adopts a quantitative research methodology by surveying 184 insurance agents in Sabah, Malaysia in 2019. Four hypotheses were tested with validated measures of job satisfaction (pay, supervision and communication), turnover intention and person-organization fit. The study revealed that job satisfaction (pay and supervision) has a significant and negative impact to turnover intention. In addition, job satisfaction (communication in organization) has a significant and positive impact to turnover intention. However, person-organization fit found to be not significantly mediates the relationship. The study suggested that organizations should acknowledge the importance of pay, supervision and communication in organization to improving employees' motivation and retention in organization. The three elements of job satisfaction could improve and promote harmonious and positive work environment.

Keywords: job satisfaction, turnover intention, person-organization (P-O) fit, insurance agents, Malaysia

\section{Introduction}

In the past, one of the reasons why employee leaving their job is due to the feeling of demanding on better compensation and ambition such higher salaries, quicker job promotions, as well as other attractive compensation packages (Waldmeir, 2012). Thus, employees are willing to leave their job with an alternative job offer (Mano-Negrin \& Tzafrir, 2004). There is a shift in this pattern recently, which shows that youth workers resigned from their job due different demands. These new generations of workers are seeking for a relaxing work environment, strategic compensation practices, flexible working hours with workplace policies that promotes work-life balance (Sang et al., 2009; Hughes \& Bozionelos, 2007).

Furthermore, Coetzee and Roythorne-Jacobs (2007) suggested five reasons and directions of the changing nature of careers, including (ii) more frequent career transitions, (ii) more frequent career decision making, (iii) the expansion of job opportunities for qualified employees, (iv) marginalised groups, and (v) more fragmented and mobile careers are especially characteristic of woman, technical specialists, people in small enterprises and in service jobs. As consequences of the changing nature of careers, it became more unstable for these group of employees, namely, short-term employees, part-time workers and on-hired. In addition, Arnold (1997) also have identified some trends in the workplace which have shifted the nature of employment, which includes outsourcing, short-term contracts, disappearance of organizational career structures, changing skill requirements, diversity in the labour force, ageing population, working at or from home, self-employment and employment insecurity. The changing nature of career explained how the nowadays jobs are formed.

Furthermore, organization views employees' turnover as costly, especially the voluntary turnover (Judge, 1993; Dess \& Shaw, 2001; Barrick et al., 1994; McElroy et al., 2001). The costs could be seen through employee re-recruitment, the tangible and intangible costs of re-training as well as customers' loyalty. Therefore, to avoid this voluntary turnover, organization must promote strategic recruitment, training, compensation packages as well as 
to implement holistic employee-centered counseling practices (Bloomquist \& Kleiner, 2000; Townsend, 2007; Nourayi \& Mintz, 2008; Dalsem, 2009; Savickas et al., 2009). In addition, HRM practices such as training and development as compensation packages together with career strategy were found to be significantly influencing career satisfaction among employees in the insurance sector (Yean \& Yahya, 2013). Moreover, HR factors such as rewards, training, teamwork, empowerment found to influence insurance agents' performance (Piaralal et al. 2014). Other recent research revealed that work-life balance practices significantly influence employee job performance and satisfaction (Dousin et al., 2019). The study aims to investigate the relation between job satisfaction and turnover intention as well as the mediating influence of person-organization fit (P-O fit) among insurance agents in Sabah, Malaysia. At present, there is a little research on these issues specifically in the insurance industry in the state of Sabah, Malaysia. The study proposed two research questions to be investigated, (i) what is the relationship between employee job satisfaction and turnover intention? and (ii) does person-organization fit ( $\mathrm{P}-\mathrm{O}$ fit) mediates the relation between employee job satisfaction and turnover intention? A quantitative research method was implemented with a survey questionnaire utilized for data collection, besides a snowball sampling was applied to recruit participants.

\section{Literature Review}

\subsection{Turnover Intention}

In several early HRM literatures, scholars defined turnover intention as employees' absenteeism after they had experienced job dissatisfaction (Porter \& Steers, 1973; Porter et al., 1974; Koch \& Steers, 1978). It is also being observed as employees' direction of resignation or seeking another occupational opportunity on thinking due to the feeling of dissatisfied with the current job (Mobley et al., 1978). Moreover, several researchers during this era suggested that one's situation change as an organization member as a generalized view on turnover, which refers to employees' recruitment, retirement, promotion, demotion and transferring (Price, 1977; Price, 1989).

These definitions have evolved over the years. Several literatures highlighted the impact of turnover by proposing functional and dysfunctional turnover. Functional turnover will bring positive impact to the organization, as an example, during the period of a company experiencing a rationalizing process, and encouraging people to leave, if some employees applied for resignation, this resignation is a functional turnover for the organization (Dalton et al., 1982). A scenario for a dysfunctional turnover occurs when a talented employee left the organization, and this can be seen to bring a negative result to the organization (Park et al., 1994). On the other hand, turnover intention also can be explored through voluntary and involuntary turnover. Voluntary turnover refers to employees resigned from current occupation because of retirement, emigration, changing compensation, job transfer, and due to employee dissatisfaction reason, an employee terminates the job contract (Judge, 1993; Dess \& Shaw, 2001). Involuntary turnover was defined as employees are discharged and dismissed by an employer, due to employer's convenience (Barrick et al., 1994; McElroy et al., 2001). 
In recent literatures, the topic has been heavily debated and discussed in various context. There are several organizational factors influencing employee turnover intention, namely, leadership, job satisfaction, employee personality fit, organizational culture, innovative work, salary and job stress (Yang et al., 2011; Albrecht \& Andreetta, 2011; Wells \& Peachey, 2011; Shih \& Susanto, 2011; Cottrell, 2011; Tian-Foreman; 2009; Park \& Kim, 2009). In most studies, there are four key factors to influence employees' turnover intention, namely: (i) personnel, (ii) organizational, (iii) organizational and individual fit as well as (iv) other external factors.

Personnel-related variables consists of factors that are fully controlled by individual employees, such as demographic (e.g. age, gender, education and job tenure), job satisfaction and organizational commitment as well as other related personal factors such as individual performance and their role in a family (Steers \& Mowday, 1981; Iverson, 1999; Griffeth et al., 2000; Dalton et al., 1997; Adams et al., 2010). The study focuses on the relationship between job satisfaction and turnover intention as well as the mediating effect of person-organization fit to be further investigated among insurance agents in Sabah, Malaysia.

\subsection{Employee Job Satisfaction and Person-Organization Fit}

Job satisfaction is comprehensively defined as the pleasurable or positive emotional state which results from the evaluation of an individual's job or job experience. Job satisfaction is a result of an employee's perception of how worth the outcome by doing a job that matches with the effort which they put into finishing the job (Weiss, 2002). Several studies proposed that pay, promotion, supervision, fringe benefits, contingent rewards, co-workers, nature of the work, and communication are key factors to influence job satisfaction (Toker, 2011; Zeffane et al., 2008; Alonderiene 2010; Gustainiene \& Endriulaitiene, 2009). Person-organization fit (P-O fit) refers to how company recruit its employees' by examining their suitability with the job (Khalida \& Saftiri, 2016). Most organizations are still using this traditional approach because they believe that it can help the organization to select potential employees who uphold principles and values which support the organization and institute the experiences that can reinforce the suitability. The concept of $\mathrm{P}-\mathrm{O}$ fit is defined as an individual willingness to maintain and hold job satisfaction and commitment which are required by the organization (Bowen, Ledrof \& Nathan, 1991).

In one of the earliest studies by March and Simon (1958), job satisfaction has been identified as one of the key factors contributing to employees' turnover intention. Evans (1998) suggested that employee job satisfaction depends on the fulfilment of their needs. Further, Marques et al. (2007) argued that motivation is the reason (needs) for people perform better in an organization; satisfaction is the award obtaining after a performance. Their study illustrated that job satisfaction study, indeed, is a measurement process on employee motivation. The study investigates three elements of job satisfaction, namely (i) pay, (ii) supervision and (iii) communication in organization. These debates lead to the following hypothesis to be tested in the study:

H1: There is a significant relation between job satisfaction (pay) and turnover intention 
H2: There is a significant relation between job satisfaction (supervision) and turnover intention

H3: There is a significant relation between job satisfaction (communication in organization) and turnover intention

Studies on person-organization (P-O) fit have emphasized the effects on employee attitudes especially on job satisfaction (Meglino et al., 1989), and turnover intention (Schneider et al., 1995). P-O fit researchers have explained the situation of relationship between P-O fit and job satisfaction as the degree of an individual's and organization's values overlap, calls value-goal congruence which refers to the more employees feels satisfied in their job, they have a higher likelihood of staying in the job (Chatman, 1991; Kristof, 1996). Another study revealed that the higher moral intensity showed by employees, it strengthens the relations between P-O fit, satisfaction and commitment (Andrews et al. 2011). Thus, these arguments lead to the following hypothesis:

\section{H2: Person-organization fit significantly mediates the relation between job satisfaction and turnover intention}

The conceptual framework of the study was developed based on the literature review above. Figure 1.0 shows the relationships between job satisfaction, turnover intention and organizational commitment.

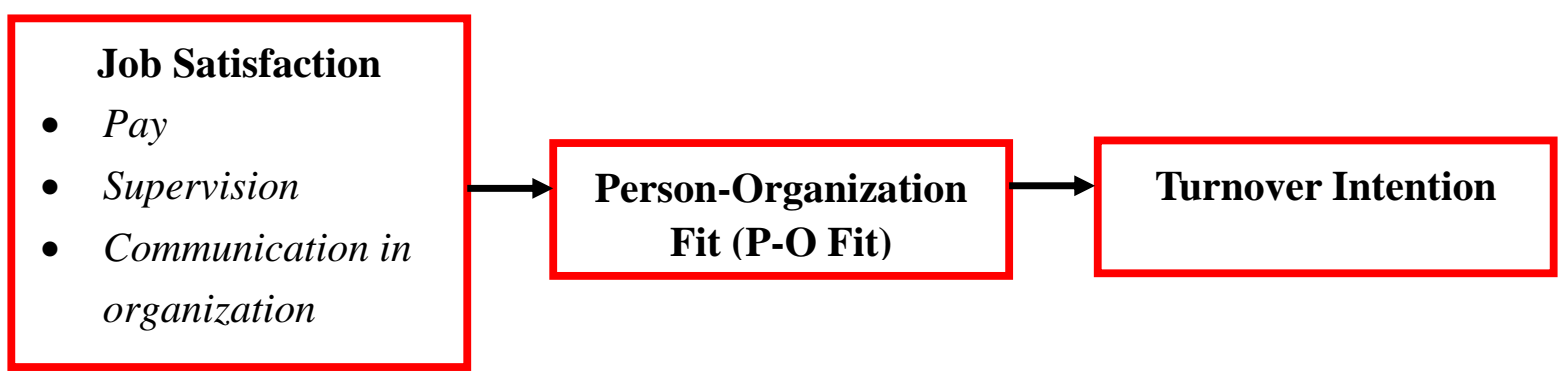

Figure 1.0. Conceptual framework: The relationship between job satisfaction, turnover intention and organizational commitment

\section{Research Methodology}

The objective of this study is to examine the relationship between job satisfaction and turnover intention as well as the mediating effect of P-O fit in the relationships, among insurance agents in Sabah, Malaysia. A quantitative research method was employed and data was collected through a survey questionnaire. The scope of this study was insurance agents in Sabah, Malaysia by implementing a random stratified sampling. A total of 250 survey questionnaires were distributed, and 184 surveys were useable for data analysis using Statistical Package for Social Science (SPSS), version 23.0, indicating a 73.60\% response rates.

The survey questionnaire was design with five sections, namely: Part A: Demographic background, Part B: Job satisfaction (pay), Part C: Job satisfaction (supervision), Part D: Job satisfaction (Communication in organization), Part E: Turnover intention and Part F: 


\section{Mll Macrothink}

International Journal of Human Resource Studies

ISSN 2162-3058 2020, Vol. 10, No. 2

Person-organization fit. The survey questionnaire was designed and developed based on adaptation and modifications of measurement items used by previous studies and researchers. Pilot test was conducted to measure the reliability and validity of each variables of the study.

The test of reliability showed that the Cronbach's alpha $(\alpha)$ for each variable exceeded the acceptable threshold of 0.7 suggested by Sekaran and Bougie (2016). The Cronbach's alpha $(\alpha)$ values for each variable are as follow: Part B: Job satisfaction (pay) (0.93), Part C: Job satisfaction (supervision) (0.94), Part D: Job satisfaction (Communication in organization) (0.93), Part E: Turnover intention (0.94) and Part F: Person-organization fit (0.88).

\section{Data Analysis}

The data of the study are self-reported, from a single source and were obtained using a single method of a 5-point Likert scale. In analyzing the common method variance (CMV), the study implemented the Harman's single factor analysis (Podsakoff et al., 2003) by conducting a principal component analysis on all the measurement items. The analysis revealed that the first component explains $33.36 \%$ of total variance in the items which is below the threshold value of 50\%, this indicated that there is no CMV problems (Podsakoff \& Organ, 1986).

Table 1.0 below shows the demographic profile for participants of the study. Most participants were female $(60.3 \%)$, aged between 26 to 35 years old $(46.2 \%)$ with a length of service as insurance agents of 1 to 5 years $(40.2 \%)$. Most participants earned RM 1001 to RM 2500 of monthly salary $(32.1 \%)$.

Table 1.0. Demographic Profile

\begin{tabular}{|c|c|c|c|}
\hline Gender (\%) & Age $(\%)$ & Length of Service & Monthly Income (\%) \\
\hline Female $=60.3$ & 21-25 years old $=$ & $(\%)$ & $<\mathrm{RM} 1000=6.0$ \\
\hline \multirow[t]{6}{*}{ Male $=39.7$} & 24.5 & $<1$ year $=20.1$ & RM1001-RM2500 = 32.1 \\
\hline & 26-35 years old $=$ & $1-5$ years $=40.2$ & $\mathrm{RM} 2501-\mathrm{RM} 4000=25.5$ \\
\hline & 46.2 & $6-10$ years $=17.4$ & RM4001- RM5500 = 14.1 \\
\hline & 36-45 years old $=$ & $11-15$ years $=10.3$ & RM5501-RM7000 = 6.0 \\
\hline & 17.9 & $16-20$ years $=8.2$ & RM7001-RM8500 = 8.2 \\
\hline & $>46$ years old $=11.4$ & $>21$ years $=3.8$ & $>\mathrm{RM} 8501=8.2$ \\
\hline
\end{tabular}

$\mathrm{N}=184$

Furthermore, table 2.0 below shows the results of Pearson correlation analysis. The result of the correlation coefficients for all relationships between variables was lesser than 0.90 , which indicates that data of the study were not affected by serious collinearity problems (Hair et al., 1998). Besides, Cronbach's alpha $(\alpha)$ for each variable exceeded 0.7, a threshold recommended by Sekaran and Bougie (2016). 


\section{Macrothink}

Table 2.0. Pearson Correlation Analysis

\begin{tabular}{lcccccc}
\hline & 1 & 2 & 3 & 4 & 5 & \\
\hline $\begin{array}{l}\text { 1. Job Satisfaction: Pay } \\
\text { 2. Job Satisfaction: }\end{array}$ & 1 & $\mathbf{0 . 9 3}$ & & & & \\
$\begin{array}{l}\text { Supervision } \\
\text { 3. Job Satisfaction: }\end{array}$ & -0.05 & $0.21^{* *}$ & 1 & $\mathbf{0 . 9 3}$ & & \\
$\begin{array}{l}\text { Communication in } \\
\text { Organization }\end{array}$ & & & & & & \\
$\begin{array}{l}\text { 4. Person-Organization } \\
\text { (P-O) Fit }\end{array}$ & $0.41^{* *}$ & $0.43^{* *}$ & 0.00 & 1 & $\mathbf{0 . 9 4}$ & \\
5. Turnover Intention & $-0.41^{* *}$ & $-0.21^{* *}$ & $0.34^{* *}$ & $-0.21^{* *}$ & 1 & $\mathbf{0 . 8 8}$ \\
\hline
\end{tabular}

$\mathrm{N}=184, * \mathrm{p}<0.05, * * \mathrm{p}<0.01, * * * \mathrm{p}<0.001$; Cronbach alphas are presented on the diagonal in bold.

As shown in table 2.0 above, job satisfaction: pay has a significant negative relationship with turnover intention $(\mathrm{r}=-0.41, \mathrm{p}<0.01)$, thereby $\mathrm{H} 1$ is supported. Moreover, job satisfaction: supervision also has a significant negative relationship with turnover intention $(r=-0.21$, $\mathrm{p}<0.01$ ), therefore, $\mathrm{H} 2$ is supported. In addition, job satisfaction: communication in organization has a significant positive relationship to turnover intention $(r=0.34, p<0.01)$, then, $\mathrm{H} 3$ is supported.

A procedure proposed by Baron and Kenny (1986) was implemented to test hypothesis 4 of the study. As discussed in Bartram et al., (2012), "whereby mediation effects can be claimed if: (i) the independent variable significantly predicts the independent variable; (ii) the independent variable significantly predicts the mediating variable; (iii) when the dependent variable is regressed simultaneously on the independent variable and the mediator, the mediator significantly predicts the dependent variable is less than that obtained in Condition 1. If the independent variable has a significant effect in Condition 3, then there is partial mediation. If the independent variable has a non-significant effect in Condition 3, then there is full mediation. According to Baron and Kenny (1986) only condition 2 and condition 3 are needed to demonstrate mediation effects" (Bartram et al., 2012). The testing of the mediating effect of P-O fit in the relationship between job satisfaction and turnover intention is shown in Table 3.0 below. The analysis revealed that hypothesis 4 is not supported. 
Table 3.0. Testing the mediating effect of Person-Organization (P-O) Fit using Baron and Kenny (1986) procedure

\begin{tabular}{lll}
\hline Variables & Step 1 & Step 2 \\
\hline Job Satisfaction: Pay & $-0.22^{* *}$ & $-0.20 * *$ \\
Job Satisfaction: Supervision & $-0.18^{* * *}$ & $-0.17^{*}$ \\
Job Satisfaction: Communication in & $0.33^{* * *}$ & $0.33^{* * *}$ \\
Organization & & \\
Person-Organization (P-O) Fit & & -0.04 \\
& & \\
R Square & $0.34^{* * *}$ & 0.384 \\
Adjusted R Square & $0.35^{* * *}$ & 0.35 \\
R Square Change & $0.21^{* * *}$ & 0.00 \\
\hline
\end{tabular}

Dependent variable: Turnover Intention, $\mathrm{N}=184,{ }^{*} \mathrm{p}<0.05,{ }^{*} \mathrm{p}<0.01$, ***p $<0.001$

\section{Discussion and Conclusion}

All variables in the study were proven valid and reliable. Furthermore, the results also demonstrated that there was a direct and significant relationship between all variables of job satisfaction (e.g. pay, supervision and communication in organization) towards turnover intention. This finding is consistent with previous studies by Sukriket (2014), Alam and Asim (2019), Mahdi et al. (2012) and Toker (2011). This study revealed that a low pay and employment benefits as well as negative experience with supervisors or managers will increase intention to leave among insurance agents in Malaysia. Pay and employment benefits could be referred to as organizational rewards which reflects the way the organization facilitate and motivate task performance and maintain organizational membership (Madhi et al., 2012; Katz \& Maanan, 1977; Mottaz, 1988). The concept of satisfaction with supervision in an organization emphasizes on the role of managers, superiors and supervisors to maintaining harmony and promoting work positive environment, which could decrease insurance agents' intention to leave and eventually improves job satisfaction. Moreover, the study also revealed that a positive communication process in an organization will decrease intention to leave among insurance agents in Malaysia. Communication in organization is crucial in order to manage employees' behaviour, create feedback by clarifying employees' current performance and expectations as well as for information exchange to facilitate decision making (Robbins \& Judge, 2019). Furthermore, the study revealed that person-organization $(\mathrm{P}-\mathrm{O})$ fit did not mediate the relationship between job satisfaction and turnover intention. Since most participants of the study are less than 35 years old $(70.7 \%)$ with less than 5 years of working as insurance agents $(60.3 \%)$, the concept of P-O fit is seen as irrelevant for this group of employees. They are seen to be motivated with the key elements of job satisfaction (e.g. pay, supervision and communication in organization).

In relation to practical contribution, the study suggested that current organizational practices 
should acknowledge the importance of the three elements of job satisfaction from the study. The study suggests that managers and supervisors to be able to design, develop and administer a competitive pay and employment benefits system that could meet employees' needs and expectations. It will help to improve their appreciation about the system which improves their positive work behaviour and decrease their intention to leave (Ismail et al., 2009). Secondly, a total commitment from managers and supervisors to promote harmonious and positive work environment is critical to ensure employees' feel motivated and satisfied at work. Then, an effective and transparency in a communication process is also crucial to avoid any communication conflict among members in an organization. A high-quality communication process should emphasize clarity, consistency, content and promotes connections. In a more recent research, Burlea-Schiopoiu and Mihai (2019) suggested that contemporary human resource practices such training, corporate social responsibility (CSR) and innovation is critical to improve sustainability and profitability. Thus, Malaysian insurance industry need to pay attention to these practices as it could improve the organizational financial performance, which eventually improves employee retention.

\section{References}

Adams, G. A., Webster, J. R., \& Buyarski, D. M. (2010). Development of an occupational embeddedness measure. Career Development International, 15(5), 420-436. https://doi.org/10.1108/13620431011075312

Alam, A., \& Asim, M. (2019). Relationship between job satisfaction and turnover intention. International Journal of Human Resource Studies, 9(2), 163-194. https://doi.org/10.5296/ijhrs.v9i2.14618

Albrecht, S. L., \& Andreetta, M. (2011). The influence of empowering leadership, empowerment and engagement on affective commitment and turnover intentions in community health service workers: Test of a model. Leadership in Health Services, 24(3), 228-237. https://doi.org/10.1108/17511871111151126

Alonderiene, R. (2010). Enhancing informal learning to improve job satisfaction: Perspective of SMEs managers in Lithuania. Baltic Journal of Management, 5(2), 257-287. https://doi.org/10.1108/17465261011045151

Andrews, M. C., Baker, T., \& Hunt, T. G. (2011). Values and person-organization fit: Does moral intensity strengthen outcomes? Leadership \& Organization Development Journal, 32(1), 5-19. https://doi.org/10.1108/01437731111099256

Arnold, J. (1997). Managing careers into the 21st century. London: Sage. https://doi.org/10.4135/9781446219034

Barrick, M. R., Mount, M. K., \& Strauss, J. P. (1994). Antecedents of involuntary turnover due to a reduction in force. Personnel Psychology, 47(3), 515-535. https://doi.org/10.1111/j.1744-6570.1994.tb01735.x

Barron, R., \& Kenny, D. (1986). The moderator-mediator variable distinction in social psychological research: conceptual, strategic and statistical consideration, Journal of 
$\begin{array}{lllll}\text { Personality } \quad \text { and } & \text { Social } & \text { Psychology, } & 51, & 1173-1182 .\end{array}$ https://doi.org/10.1037/0022-3514.51.6.1173

Bartram, T., Casimir, G., Djurkovic, N., Leggat, S. G., \& Stanton, P. (2012). Do perceived high performance work systems influence the relationship between emotional labour, burnout and intention to leave? A study of Australian nurses, Journal of Advanced Nursing, 68(7), 1567-1578. https://doi.org/10.1111/j.1365-2648.2012.05968.x

Bloomquist, M. J., \& Kleiner, B. H. (2000). How to reduce theft and turnover through better hiring methods. Management Research News, 23(7), 79-83. https://doi.org/10.1108/01409170010782235

Bowen, D. E., Ledford, G. E., \& Nathan, B. R. (1991). Hiring for the organization, not the job. Academy of Management Executive, 5(4), 35-49. https://doi.org/10.5465/ame.1991.4274747

Burlea-Schiopoiu, A., \& Mihai, L. S. (2019). An integrated framework on the sustainability of SMEs. Sustainability, 11(21), 1-22. https://doi.org/10.3390/su11216026

Chatman, J. A. (1991). Matching people and organizations: Selectin and socialization in public accounting firms. Administrative Science Quarterly, 36(3), 459-484. https://doi.org/10.2307/2393204

Coetzee, M., \& Roythorne-Jacobs, H. (2007). Career counselling and guidance in teh workplace: A manual for career practitioners (first ed.). Cap Town: Juta \& Co.

Cottrell, T. (2011). Moving on: Salaries and managing turnover. The Bottom Line: Managing Library Finances, 24(3), 187-191. https://doi.org/10.1108/08880451111186044

Dalsem, S. V. (2009). Maturity policies of CEO severance contracts and forced internal turnover. Managerial Finance, 35(9), 772-783. https://doi.org/10.1108/03074350910973694

Dalton, D. R., Hill, J. W., \& Ramsay, R. J. (1997). Women as managers and partners: Context specific predictors of turnover in international public accounting firms. A Journal of Practice \& Theory, 16, 29-50. https://doi.org/10.1016/S0278-4254(97)00025-2

Dalton, D. R., Todor, W. D., \& Karckhardt, D. M. (1982). Turnover overstated: The functional taxonomy. The Academy of Management Review, 7, 117-123. https://doi.org/10.5465/amr.1982.4285499

Dess, G. G., \& Shaw, J. D. (2001). Voluntary turnover, social capital, and organizational performance. The Academy of Management Review, 26(3), 446-456. https://doi.org/10.5465/amr.2001.4845830

Dousin, O., Collins, N., \& Kler, B. K. (2019). Work-life balance, employee job performance and satisfaction among doctors and nurses in Malaysia. International Journal of Human Resource Studies, 9(4), 306-319. https://doi.org/10.5296/ijhrs.v9i4.15697

Evans, L. (1998). Teacher Morale, Job Satisfaction and Motivation. London: SAGE Publications. 


\section{$\triangle$ Macrothink}

International Journal of Human Resource Studies

ISSN 2162-3058

2020, Vol. 10, No. 2

Griffeth, R. W., Hom, P. W., \& Gaertner, S. (2000). A meta-analysis of antecedents and correlates of employee turnover: Update, moderator tests, and research implications for the next millennium. Journal of Management, 26(3), 463-488. https://doi.org/10.1177/014920630002600305

Gustainiene, L., \& Endriulaitiene, A. (2009). Job satisfaction and subjective health among sales managers. Baltic Journal of Management, 4(1), 51-65. https://doi.org/10.1108/17465260910930449

Hair, J. F., Anderson, R. E., Tatham, R. L. \& William, C. (1998). Black (1998), Multivariate data analysis, Upper Saddle River, NJ: Prentice Hall.

Hughes, J., \& Bozionelos, N. (2007). Work-life balance as source of job dissatisfaction and withdrawal attitudes: An exploratory study on the views of male workers. Personnel Review, 36(1), 145-154. https://doi.org/10.1108/00483480710716768

Ismail, A., Dousin, O., Girardi, A., Ahmad, Z. A., Shariff, M. N., Majid, A. H., Ibrahim, Z. (2009). Empirically testing the relationship between income distribution, perceived value of money and pay satisfaction. Intangible Capital, 5(3), 235-258. https://doi.org/10.3926/ic.2009.v5n3.p235-258

Iverson, R. D. (1999). An event history analysis of employee turnover: The case of hospital employees in Australia. Human Resource Management Review, 9(4), 397-418. https://doi.org/10.1016/S1053-4822(99)00027-3

Judge, T. A. (1993). Does affective disposition moderate the relationship between job satisfaction and voluntary turnover? Journal of Applied Psychology, 78(3), 395-401. https://doi.org/10.1037/0021-9010.78.3.395

Katz, R., \& Maanan, J. V. (1977). The loci of work satisfaction: Job interaction and policy. Human Relation, 30, 469-486. https://doi.org/10.1177/001872677703000505

Khalida, R., \& Safitri, N. (2016). The effect of person-organization fit on turnover intention with job satisfaction as mediating variable. International Journal of Administrative Science \& Organization, 23(3), 120-130. https://doi.org/10.20476/jbb.v23i3.9173

Koch, J. L., \& Steers, R. M. (1978). Job attachment, satisfaction, and turnover among public sector employees. Journal of Vocational Behavior, 12(1), 119-128. https://doi.org/10.1016/0001-8791(78)90013-1

Kristof, A. L. (1996). Person-organization fit: An integrative review of its conceptualizations, measurement, and implications. Personnel Psychology, 49(1), 1-49. https://doi.org/10.1111/j.1744-6570.1996.tb01790.x

Mahdi, A. F., Zin, M. Z. M., Nor, M. R. M., Sakat, A. A., \& Naim, A. S. A. (2012). The relationship between job satisfaction and turnover intention. American Journal of Applied Sciences, 9(9), 1518-1526. https://doi.org/10.3844/ajassp.2012.1518.1526

Mano-Negrin, R., \& Tzafrir, S. S. (2004). Job search modes and turnover. Career 
Development International, 9(5), 442-458. https://doi.org/10.1108/13620430410550727

March, J. G., \& Simon, H. A. (1958). Organizations. New York: Wiley.

Marques, J., Dhiman, S., \& King, R. (2007). Spirituality in the Workplace: What It Is, Why It Matters, How to Make It Work for You: Personhood Press.

McElroy, J. C., Morrow, P. C., \& Rude, S. N. (2001). Turnover and organizational performance: A comparative analysis of the effects of voluntary, involuntary, and reduction-in-force turnover. Journal of Applied Psychology, 86(6), 1294-1299. https://doi.org/10.1037/0021-9010.86.6.1294

Meglino, B. M., Ravlin, E. C., \& Adkins, C. L. (1989). A work values approach to corporate culture: A field test of the value congruence process and its relationship to individual

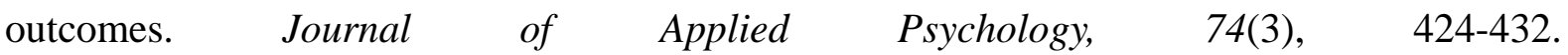
https://doi.org/10.1037/0021-9010.74.3.424

Mobley, W. H., Horner, S. O., \& Hollingsworth, A. T. (1978). Ation of evaluation of precursors of hospital employee turnover. Journal of Applied Psychology, 63(4), 408-414. https://doi.org/10.1037/0021-9010.63.4.408

Mottaz, C. J. (1988). Determinants of organizational commitment. Human Relation, 41, 467-482. https://doi.org/10.1177/001872678804100604

Nourayi, M. M., \& Mintz, S. M. (2008). Tenure, firm's performance, and CEO's compensation. Managerial Finance, 34(8), 524-536. https://doi.org/10.1108/03074350810874055

Park, H. Y., Dankwa, J. O., \& Bishop, D. R. (1994). Organizational and environmental determinants of functional and dysfunctional turnover: Practical and research implications. Human Relations, 47(3), 353-366. https://doi.org/10.1177/001872679404700306

Park, J. S., \& Kim, T. H. (2009). Do types of organizational culture matter in nurse job satisfaction and turnover intention. Leadership in Health Services, 22(1), 20-38. https://doi.org/10.1108/17511870910928001

Piaralal, N. K., Mat, N., Piaralal, S. K., \& Bhatti, M. A. (2014). Human resource management factors and service recovery performance in Malaysian life insurance industry: Exploring the moderating effects of employment status. European Journal of Training and Development, 38(6), 524-552. https://doi.org/10.1108/EJTD-07-2013-0078

Podsakoff, P. M., \& Organ, D. W. (1986). Self-reports in organizational research: Problems and prospects, Journal of Management, 12(4), 531-44. https://doi.org/10.1177/014920638601200408

Podsakoff, P. M., MacKenzie, S. B., Lee, J. Y., \& Podsakoff, N. P. (2003). Common method biases in behavioral research: a critical review of the literature and recommended remedies, Journal of Applied Psychology, 88(5), 879. https://doi.org/10.1037/0021-9010.88.5.879

Porter, L. W., \& Steers, R. M. (1973). Organizational work and personal factors in employee 
turnover and absenteeism. Psychological Bulletin, 80, 151-176. https://doi.org/10.1037/h0034829

Porter, L. W., Steers, R. M., Mowday, R. T., \& Boulian, P. V. (1974). Organizational commitment, job satisfaction, and turnover among psychiatric technicians. Journal of Applied Psychology, 59(5), 603-609. https://doi.org/10.1037/h0037335

Price, J. L. (1977). The Study of Turnover: Iowa State University Press (Ames).

Price, J. L. (1989). The impact of turnover on the organization. Work and Occupations, 16(4), 461-473. https://doi.org/10.1177/0730888489016004005

Robbins, S. P., \& Judge, T. A. (2019). Organizational Behavior, $18^{\text {th }}$ Ed. Pearson Education, United Kingdom.

Sang, K. J. C., Ison, S. G., \& Dainty, A. R. J. (2009). The job satisfaction of UK architects and relationships with work-life balance and turnover intentions. Engineering Construction and Architectural Managment, 16(3), 288-300. https://doi.org/10.1108/09699980910951681

Savickas, M. L., Nota, L., Rossier, J., Dauwalder, J.-P., Duarte, M. E., Guichard, J., et al. (2009). Life designing: A paradigm for career construction in the 21st century. Journal of Vocational Behavior, 1-12. https://doi.org/10.1016/j.jvb.2009.04.004

Schneider, B., Goldstiein, H. W., \& Smith, D. B. (1995). The ASA framework: An update. Personnel Psychology, 48(4), 747-773. https://doi.org/10.1111/j.1744-6570.1995.tb01780.x

Sekaran, U., \& Bougie, R. (2003). Research methods for business: A skill building approach, John Wiley and Sons Inc., New York.

Steers, R. M., \& Mowday, R. T. (1981). Employee turnover and post-decision accommodation process. In L. L. Cummings \& B. M. Staw (Eds.), Research in Organizational Behavior (1, 235-281). Greenwich: JAI Press.

Sukriket, P. (2014). The relationship between job satisfaction and turnover intention of Thai software programmers in Bangkok, Thailand. AU Journal of Management, 12(2), 42-52.

Tian-Foreman, W. (2009). Job satisfaction and turnoverin the Chinese retail industry. Chinese Management Studies, 3(4), 356-378. https://doi.org/10.1108/17506140911007503

Toker, B. (2011). Job satisfaction of academic staff: An empirical study on Turkey. Quality Assurance in Education, 156-169. https://doi.org/10.1108/09684881111125050

Townsend, K. (2007). Recruitment, training and turnover: another call centre paradox. Personnel Review, 36(3), 476-490. https://doi.org/10.1108/00483480710731383

Waldmeir, P. (2012). China workers discover there's life after luoci. Retrieved 12 March, 1012, from http://www.ftchinese.com/story/001043588/en

Weiss, H. M. (2002). Deconstructing job satisfaction: Separating evaluations, beliefs and affective experiences. Human Resource Management Review, 12(2), 173-194. https://doi.org/10.1016/S1053-4822(02)00045-1 


\section{Macrothink}

International Journal of Human Resource Studies

ISSN 2162-3058 2020, Vol. 10, No. 2

Wells, J. E., \& Peachey, J. W. (2011). Turnover intentions: Do leadership behaviors and satisfaction with the leader matter? Team Performance Management, 17(1/2), 23-40. https://doi.org/10.1108/13527591111114693

Yang, C., Ma, Q., \& Hu, L. (2011). Job embeddedness: A new perspective to predict voluntary turnover. Nankai Business Review International, 2(4), 418-446. https://doi.org/10.1108/20408741111178834

Yean, T. F. \& Yahya, K. K. (2013). The influence of human resource management practices and career strategy on career satisfaction of insurance agents. International Journal of Business and Society, 14(2), 193.

Zeffane, R., Ibrahim, M. E., \& Mehairi, R. A. (2008). Exploring the differential impact of job satisfaction on employee attendance and conduct: The case of a utility company in the United Arab Emirates. Employee Relations, 30(3), 237-250. https://doi.org/10.1108/01425450810866514

\section{Copyright Disclaimer}

Copyright for this article is retained by the author(s), with first publication rights granted to the journal.

This is an open-access article distributed under the terms and conditions of the Creative Commons Attribution license (http://creativecommons.org/licenses/by/4.0/). 